\title{
El pasado inasequible. Desaparecidos, hijos y combatientes en el arte y la literatura del nuevo milenio
}

\author{
Blejmar, Jordana; Mandolessi, Silvana y Pérez, Mariana Eva (comps.) (2018) \\ Buenos Aires, Eudeba, 352 pp.
}

\section{(4) Agostina Invernizzi UBA-Conicet}

El pasado inasequible. Desaparecidos, hijos y combatientes en el arte y la literatura del nuevo milenio reúne los ensayos críticos de dieciocho investigadoras/es y escritoras/es que participaron del congreso internacional New Poetics of Disappearence: Literature, Violence and Memory, llevado a cabo en la Universidad de Londres el 16 y 17 de junio de 2014.

El volumen recoge las reflexiones sobre los cambios producidos en materia de representación en las obras centradas en la desaparición, los hijos y los combatientes de la Guerra de Malvinas, gestadas al calor del nuevo milenio. Si durante la dictadura el arte recurre a estrategias elípticas y a lenguajes opacos para dar cuenta del horror de los crímenes, esbozando siluetas que con su inscripción en el espacio público lo tornan visible, ¿qué formas adquieren los diferentes lenguajes artísticos cuando, de algún modo, lo indecible ingresa en los discursos sociales y el pasado comienza a asimilarse? Los modos testimoniales de las estéticas de comienzos de la democracia vislumbran nuevas formas para narrar el pasado. Porque además, los tiempos del arte corren de manera oblicua a los tiempos de la historia y la política. El arte se sitúa en otra dimensión y siempre quiere decir "algo más". Es en ese excedente donde, muchas veces, el arte se adelanta a la historia.

Este libro dialoga con otros trabajos que desde la recuperación de la democracia apenas se ocuparon de pensar cuestiones inherentes a la memoria, a la cultura y a la política. Pero además, ya desde el título, Jordana Blejmar, Silvana Mandolessi y Mariana Eva Pérez ponen de manifiesto la dificultad de aproximarnos a un pasado que ante todo se resiste a ser alcanzado y que persiste en el presente acechando a una sociedad entera. Las compiladoras comparten con Georges DidiHuberman y Walter Benjamin una concepción del pasado como montaje, entendido como una sumatoria de tiempos heterogéneos, y nos invitan a acercarnos a él desde esa hibridez.
En esta propuesta, el 24 de marzo de 2004 toma carácter de "acontecimiento", aquello que Badiou identifica como la apertura a la contingencia, a lo que, desde el estricto punto de vista de la legalidad de un mundo, es propiamente imposible. Así, actos simbólicos impulsados por Néstor Kirchner como la remoción de los cuadros de los genocidas en el Colegio Militar y el pedido de perdón "en nombre del Estado argentino", junto con la conversión a museo de la memoria de lo que antes funcionaba como campo de exterminio, crean nuevas posibilidades de enunciación y de acción. Es en torno a los intersticios de este acontecimiento que circulan las producciones estéticas abordadas en el libro, que tienen como límite el año 2015, comienzo de la gestión macrista, cuando asistimos a un retroceso en las políticas de la memoria; $y$, al mismo tiempo, cuando se observan otros acercamientos y reposicionamientos sobre el pasado en comparación con las décadas previas.

La primera sección, "Figuras espectrales", condensa una serie de ensayos que analizan las estrategias de representación de la figura del desaparecido en el arte y la literatura del nuevo milenio. La categoría de lo espectral atraviesa las diferentes producciones. El segmento inicia con "Recordad desde lejos: el trabajo de una cita fantasmal" de Sylvia Molloy, donde la autora examina la experiencia de regresar al país desde el exilio en la transición hacia la democracia, y confrontarse con las huellas de la desaparición en una ciudad que aún "no se había recuperado del todo" (p. 39). Molloy narra su experiencia, junto con las de otros escritores, como Tununa Mercado en En estado de memoria, o Edgardo Cozarinsky en Vudú urbano, y las imagina como postales fantasmagóricas o crónicas escritas en estado de memoria. Es decir, "reconstruyendo un pasado-presente con recuerdos fantasmagóricos que colman los vacíos" (p. 40).

A continuación, el trabajo de Silvana Mandolessi es fundamental para pensar la articulación interna del libro. La autora trabaja con la filosofía del tiempo, la 
teoría del trauma y los estudios de memoria. Discute la temporalidad paradójica de la desaparición que, en tanto tecnología represiva, disloca la concepción lineal del tiempo y requiere ser pensada desde una temporalidad alternativa más allá de la historia y del trauma. Mandolessi encuentra esa posibilidad en la figura del espectro que puja por regresar y desestabiliza nuestro presente. Por último, interroga algunas ficciones que se ocupan de esa temporalidad espectral: Los topos (2008) de Félix Bruzzone, Los planetas (1999) de Sergio Chejfec, y Chicos que vuelven (2010) de Mariana Enríquez.

El texto de Martín Kohan toma como objeto de estudio la muestra fotográfica de Helen Zout, Huellas de desapariciones, y analiza las estrategias para fotografiar lo ausente. En este sentido, el autor se aproxima a los planteamientos teóricos que oscilan entre la irreprensentabilidad de las imágenes (Agamben) o aquellos que contemplan las imágenes frente a todo (Didi-Huberman). Para Kohan, es clave pensar en la "desaparición" y no en "desparecidos" en el trabajo de Zout, es decir, en una acción y un estado, y no en quienes sufrieron esa acción. En consecuencia, el autor vislumbra en las imágenes la búsqueda de esas marcas. A partir de recursos como juegos de luces y de sombras, movimientos de cámara y fuera de foco, Zout se acerca al "esto ha sido" de la fotografía anunciado por Barthes.

En su trabajo "En busca del presiosaurio", Kristen Mahlke analiza la novela El lago (2005) de Paula Kaufmann. Ambas autoras se valen de la figura del monstruo para pensar la desaparición. Para Mahlke, el monstruo funciona como prisma retórico a través del cual todo aquello que está clasificado y es identificable es refractado en un espectro de posibilidades inciertas. La introducción de la desaparición forzada como modelo de represión transforma radicalmente la percepción global de los hechos y la percepción de sí mismos de narradores y protagonistas, alterando desde lo narrativo las categorías de temporalidad e identificación (p. 91).

Laura Alonso y Rodrigo Marcó del Pont centran su trabajo en la creación colectiva La Ilíada, y en el Teatro de los Andes, fundado por César Brie. Analizan la figura del desaparecido en tanto personaje construido de manera intertextual con los héroes del texto clásico e indagan en los procesos de reescritura. De esta manera, dirigen su atención hacia los vínculos que plantea Brie entre la importancia del ritual funerario en la Grecia antigua y los países latinoamericanos, y a los procedimientos específicos para darle forma a la figura de los desaparecidos. Por último, señalan las preocupaciones estéticas y políticas del Teatro de los Andes.
La sección finaliza con el trabajo de Cecilia Sosa dedicado a la campaña digital que tuvo lugar en Facebook el 24 de marzo de 2010, donde miles de usuarios removieron sus imágenes de perfil dando cuenta de la ausencia en nombre de los desaparecidos. Sosa plantea un diálogo entre los perfiles sin rostro de una comunidad anónima y las prácticas del Siluetazo en los años ochenta, y el modo en que esta campaña establece una "comunidad ampliada" que invita a repensar las relaciones de parentesco, memoria y política entre las nuevas generaciones.

La segunda sección, "Autofiguración, orfandad y desaparición", se ocupa de las narrativas de las "nuevas generaciones" de la posdictadura. En "Los juguetes no son tuyos", Ernesto Semán complejiza la noción de "literatura de hijos" que agrupa obras de diversa índole bajo la condición compartida de ser hijxs de desaparecidxs. El autor propone leer estas obras, ya no como el resultado de los avances en las políticas de la memoria, sino contra la memoria, entendida como liturgia de la desaparición. El autor vislumbra en Soy un bravo piloto de la Nueva China (2008) la posibilidad de dejar de ser hijxs de la historia para pasar a ser padres de la propia escritura.

El artículo de Rike Volte indaga las estrategias de representación del vacío y el silencio, en tanto condiciones determinadas por la ausencia por des-aparición forza$\mathrm{da}$, en dos textos posmemoriales: Diario de una princesa montonera-110\% Verdad (2012) de Mariana Eva Pérez, y Los topos (2008) de Félix Bruzzone. En el primero, la autora encuentra en el uso de un signo tipográfico -el asterisco - una estrategia de desplazamiento y borradura que apela a la desaparición en términos no testimoniales. En el segundo, la nieve funciona como el medio mimético-catalizador de derivas y ausencias. Ambos textos proponen estrategias excéntricas que rompen con los mandatos de identidad y memoria.

El trabajo de Noa Vaisman continúa el debate iniciado por Beatriz Sarlo en 2004 sobre la aplicabilidad del concepto de posmemoria para el caso argentino. Según Vaisman, la construcción de memoria en nuestro país adopta características particulares que la distinguen de otros tipos de memoria atribuidos a las posgeneraciones de contextos históricos diferentes. La desaparición de la generación de los padres dificulta el uso del término. En cambio, el autor propone el concepto de memoria desaparecida: "construida en torno a un núcleo ausente y a una presencia fantasmal" (p. 187) para describir la memoria de los hijxs de desaparecidxs, estructurada no a partir de un trauma transmitido por los padres, sino desde el vacío. El autor analiza las texturas de esa memoria en el filme $M$ (Nicolás Prividera, 2007), y en Diario de una princesa montonera (2012). 
El artículo de Jordana Blejmar analiza la narrativa de Félix Bruzzone, prestando especial atención a Las chanchas (2014). Sostiene que en el último tiempo, la literatura de Bruzzone ha experimentado un vuelco en el que el autor remueve todo tipo de referencia explícita tanto a la dictadura como a su biografía para trasladar a sus personajes a universos semifantásticos. Tópicos, personajes y lugares comunes de las ficciones posdictatoriales son des-familiarizados en la narrativa de Bruzzone. Para Blejmar, el autor renueva el género de "narrativas de la dictadura" y ofrece una especie de testimonio novelado, probando a la vez que "la ficción puede ser testimonial sin ser (auto) referencial" (p. 217).

Por su parte, Karen Saban propone una lectura del proyecto Historietas x la identidad, impulsado por Abuelas de Plaza de Mayo para narrar historias sobre la búsqueda de nietos. Analiza las estructuras lingüísticas e iconográficas que componen las historietas y que permiten narrar la memoria mediante imágenes. Concluye que este proyecto realiza una contribución a la búsqueda de niños desaparecidos además de ofrecer de manera original una forma de "historiar la memoria" a través de la relación establecida entre lo personal y lo colectivo.

Geoffrey Maguire se aboca al análisis de la película Infancia clandestina (Ávila, 2011), y a la relación entre historia y biografía, y ficción y política. En línea con el cine argentino y latinoamericano que, desde hace ya algún tiempo, se ocupa de reposicionar la agencia política en la niñez, para Maguire, la película procura un relato que sitúa la infancia en el centro del discurso y complejiza el lugar del niño dentro de la militancia. Con secuencias animadas, el filme subraya la potencia en la mirada del niño como fuente de otra perspectiva sobre el pasado dictatorial.

Por último, en "La guardería: entre la revolución y el refugio" Javier Trímboli propone una mirada sobre el documental de Virginia Croatto que recoge las experiencias del tránsito de hijxs de montoneros por el refugio infantil en La Habana durante la denominada contraofensiva. En diálogo con Arendt, Valéry, Cortázar y Walsh — referencias presentes en la película- el autor se pregunta por el modo en que estas experiencias oscilan entre la esfera pública y la privada, y por la promesa de revolución que fue reemplazada por el horror de los campos.

La tercera sección, "Contar Malvinas", subraya los modos en que los combatientes fueron nombrados en la posdictadura: "chicos de la guerra", "veteranos", "héroes" o "locos de la bandera".

Jens Andermann dirige su atención al trabajo de Juan Tavarnik, especialmente a Malvinas: retratos y paisajes de guerra (2008), donde el artista realiza una serie de entrevistas y retratos a ex combatientes de Malvinas que además complementa con imágenes de paisajes malvinenses aún marcados por la guerra. Según Andermann, Tavarnik — desde el título de su obraalude a la extensa tradición pictórica latinoamericana que pone en relación rostro/paisaje, pero lo hace desde un desplazamiento que reinscribe como herida la sutura rostro/paisaje que definía al género. Así, remite a la imposibilidad de suturar "país" y "paisanos" según la tradición genérica, la cual es forzada a revelar un problema de ciudadanía. Andermann examina el orden de los "reclamos de emergencia" en la obra de Tavarnik interviniendo críticamente en los bordes de lo no dicho a los que apelan las imágenes.

Por su parte, Patricio Pron reflexiona acerca de la experiencia infantil de la guerra desde la mirada de los miembros de su propia generación en su novela Una puta mierda (2007). De acuerdo con Pron, esta aproximación le permitió llegar a una percepción fantástica que se aleja de los discursos nacionalistas para narrar y justificar la guerra. Si Malvinas fue una ficción desde el inicio, el mejor modo de intervenir en los debates es construyendo otra ficción "como agregado y diferencia cuantitativa" (p. 323).

Por último, Victoria Torres dirige su interés hacia la literatura infantil y juvenil sobre Malvinas, poniendo especial atención a los modos de transmisión generacional de una experiencia del pasado y a la capacidad de interpelación que estas obras evocan. La autora destaca la austeridad de la novela infantil y el alejamiento del maniqueísmo, el dramatismo y la farsesca que han proliferado en las narrativas sobre el conflicto. A la par, distingue en la novela juvenil cierta polifonía que intenta poner en escena todos los puntos de vista posibles, $y$ al mismo tiempo, deja lugar para voces anómalas que abren el texto a nuevos sentidos.

De esta manera, El pasado inasequible... traza una cartografía lúcida de las transformaciones estéticas en el arte y la literatura que revisan el pasado traumático y, al mismo tiempo, permite adentrarnos en el universo representacional de obras de diversa índole ofreciendo, en algunos casos, lecturas complementarias de un mismo objeto de estudio abordado desde diferentes perspectivas. En esta aproximación híbrida hacia al pasado conviven textos de varias generaciones que, en algunos casos, justamente ponen el foco en la transmisión generacional de la memoria. Así, esta propuesta actualiza los debates entre estética y política, y amplía la memoria y sus procesos colectivos volviéndolos plurales y asequibles. 
